\title{
METHOD OF PROJECTS IN ENGLISH LANGUAGE STUDIES BY STUDENTS OF ECONOMIC SPECIALTIES AT UMAN NATIONAL UNIVERSITY OF HORTICULTURE
}

\section{Chuchmii Iryna ${ }^{1}$}

DOI: https://doi.org/10.30525/978-9934-571-89-3_32

Communicative competence is a component of the professional activity of specialists in the field of economics in modern society. That is why it is important to develop it in students of economic specialties for their further implementation in work. In our opinion, the project activity in classes of foreign languages provides for the acquisition of communicative competence through a number of the abovementioned competencies.

\footnotetext{
${ }^{1}$ Uman National University of Horticulture, Ukraine
} 
The American researcher W. Kilpatrick (1918) proposed the method of projects at the beginning of the 20th century. The main purpose of this method is to provide students with the opportunity to acquire knowledge independently in the process of solving practical problems and problems that led to the search for the necessary information in various scientific sources.

In our study, we adhere to the findings of British scientists G. Beckett and T. Sletter (2005) who believe that the main goal of the project activity is to show students how to develop speech and skills within the project work, consisting of two key components such as schedule and project diary [3, p. 110].

Application of project activity method on lessons of foreign languages undoubtedly has significant advantages. D. Fried - B ooth (1996) considers project activity as an effective way to students' self-control using the technique "I am able / I Can" [2, p. 34], which allows students to evaluate themselves according to a certain set of criteria. For their development, teachers can use techniques and prototypes of self-assessments of professional speech skills developed by the Common European Framework of Reference for Languages (CEFR) [1].

The advantages of project activities include finding ways to solve problems of using by students logic reasoning; tracking the dynamics of individual student achievements; the possibility of self-control by students of their own academic achievements; development of skills for self-education and self-control; development of group activity skills; raising information culture; development of skills for search, gathering and presentation of information; motivation increase; development of creative abilities; integration of various subjects, etc. [4].

The problem of subjective assessment of creative work is also one of the significant shortcomings of the project activity, which, however, is overcome through the development of detailed assessment criteria and analytical - global assessment scales of students' knowledge, which assess certain aspects of student project activity.

At Uman National University of Horticulture (UNUH), students of economic specialties in the course "The Foreign Language (for professional orientation)" acquire reading, writing and speaking skills within such topics as Market Economy, Business Organization, Marketing, Taxes and Taxation, "Budget and Audit" and others. The educational activity is aimed at developing foreign language communication skills among students as future specialists in various branches of the economy and is an important component in their professional development and formation.

In applying the project activity in English classes for students of economic specialties, we chose the following stages of the project activity:

1. Organizational-preparatory (selection of topics, definition of tasks of the project, problem search, conclusion of the initial plan, determination of participants, methods, methods of research, mastery of terminology).

2. Search and research (development of research program; collection and study of necessary information; direct research using observation, experiment, analysis and synthesis methods). 
3. Reporting and design (title selection of the research project, presentation of the project).

4. Information and presentation (project defence, self-assessment and evaluation of projects by other participants).

Thus, in teaching students English within the course "The Foreign Language (for professional orientation)" for students of economic specialties of UNUH, we used method of projects on certain topics. In particular, in the study of the topic "Market Economy" at the organizational and preparatory stage, we focused on the following issues: What do you think a market economy is? Does Ukraine have a market economy? What are the characteristic features of a market economy? Etc.

The method of "brainstorming" helped to intensify language skills of students and identify problems of the market economy in Ukraine. The next kind of activity that offered to students was an overview of the presentation "Fundamentals of Market Economy", studying and discussing the foundations of the market economy, led to the identification of its advantages and disadvantages through discussion in small groups. In particular, students were asked to fill in the "Advantages / Disadvantages of Market Economy" table, divide into two groups and justify "pros" and "cons" in each of the groups.

At this stage of the project activity, the metacognitive approach was also applied, which helped to put students such tasks to the article on economic problems prepared by the teacher:

- Share your thoughts (What do you think of the problems the author described in the article?);

- Analyse the most significant problem posed by the author, which in your opinion he set himself as a goal);

- Emphasize the words and phrases that cover the problem/ problems set by the author;

- Name the strategy to solve the problem;

- Identify other situations in which you can apply the above strategies.

At this stage of the project activity, students consolidated the knowledge of economic terms that were studied previously. The topics of projects for two groups of students were selected ("Problems of Ukrainian market economy" and "Global crises in the market sphere: Ukraine's experience"), defined tasks of projects and benchmarks for finding solutions to problems; plan of development of each of the projects. There were defined participants of two groups of students, determined methods and techniques of research within projects.

At the research and development stage, students developed a program of their research on market economy issues in Ukraine, collected and studied information from modern economic sources and described their observations.

At the reporting and design stage, students completed their projects and presented their results in the form of a report. Finally, the presentation of projects by two micro groups took place and assessment and self-assessment of projects took place.

The aim of this study was to describe the implementation of the project activity in foreign language classes for students of economic specialties Bachelor Degree on the 
example of UNUH within the framework of the course "The Foreign Language (for professional orientation)". The results showed that the project activity in foreign language classes for students of economic specialties could be an effective means of interactive language use and create autonomy for students in their research activities on the project. Prospects are further potential improvement of the project activity for various areas of training specialists in the economic specialties of Bachelor Degree, in particular in "Marketing", "Accounting and Taxation", "Entrepreneurship, Trade and Stock Exchanges", etc.

\section{References:}

1. Common European framework of reference for languages: Learning, teaching, assessment (2001). Cambridge: Cambridge University Press, 260 p.

2. Fried-Booth D. L. (1996). Project Work. Resource book for teachers Oxford: Oxford University Press, 89 p.

3. Gulbahar H. Beckett, Tammy Slater, The Project Framework: a tool for language, content, and skills integration, ELT Journal, Volume 59, Issue 2, April 2005, Pages 108-116, https://doi.org/10.1093/eltj/cci024

4. Kilpatrick, W. H. (1918). The project method. Teachers College Record, 19, 319-335. 